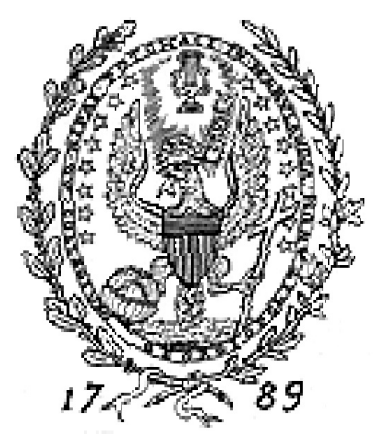

Bioethics Research Library

The Joseph and Rose Kennedy Institute of Ethics

Box 571212, Georgetown University

Washington, DC 20057-1212

202-687-3885; fax: 202-687-8089

bioethics@georgetown.edu

http://bioethics.georgetown.edu

\title{
Medical Tourism: Crossing Borders to Access Health Care
}

\author{
Harriet Hutson Gray \\ Susan Cartier Poland \\ June, 2008
}

Traveling abroad for one's health has a long history for the upper social classes who sought spas, mineral baths, innovative therapies, and the fair climate of the Mediterranean as destinations to improve their health. The newest trend in the first decade of the twenty-first century has the middle class traveling from developed countries to those with emerging economies to avoid treatment delays, prohibitive costs for life-saving procedures, or simply high costs for elective surgery. Others leave to have access to assisted suicide in countries that have legalized it: Belgium, The Netherlands, and Switzerland. This new era of globalization in health care has arrived without the benefit of international standards, government oversight, or ethical and legal review.

Howard Staab, a self-employed carpenter from North Carolina, flew to India for his medically necessary heart surgery, scheduled a side trip to the Taj Mahal, and returned home to work in North Carolina. He spent a total of less than $\$ 10,000$, instead of the $\$ 200,000$ required from the local hospital (I, Milstein and Smith 2006).

At first blush, the outsourcing of medical care to India seems to be a particular solution for a particular problem. However, the particularity of Mr. Staab is not unique. His experience is emblematic of those patients in the United States with a medical need for major and elective procedures, but who also must bear the total cost of these procedures. These middle-class, under-insured Americans go abroad. 
In tandem with increasingly aggressive marketing campaigns, American hospitals and companies have begun to leverage their connections in Asia to grow the medical tourism business into a major economic force. What are the consequences of this?

Several authors point to the effect on the host country's population, particularly the poor, to be pushed farther down the queue to receive adequate, affordable care. Resources are applied to the foreign trade instead of building the local medical infrastructure. Another potential problem is the obligation of the home-country physician to provide follow-up care. What are the legal ramifications when the procedure was illegal to begin with? Are there opportunities for redress for medical errors?

These factors may be converging into a "perfect storm" for health care in the U.S., in which the potential participation of the major insurance companies in promoting offshore care will be the tipping point in the precarious structure that represents the economic currents in health care. Third-party administrators and self-funded employers may be on the cutting edge in 2009 by providing incentives to employees to travel overseas for care.

\section{ECONOMIC CONSIDERATIONS}

Connell, John. Medical Tourism: Sea, Sun, Sand and . . Surgery. Tourism Management 27: 1093-1100, 2006.

As evidence of the interest of traditional tour operators in this newer twist on the industry, the author explores medical tourism as an element of the growth of world tourism. In promoting medical tourism, he urges consideration of such issues as the privatization of health care, the foundational role of technology, and uneven access to health resources.

Dunn, Philip. Medical Tourism Takes Flight.
$H$ and HN: Hospitals and Health Networks: 40-44, November 2007.

Writing for U.S. health care executives, Dunn emphasizes that the reality of medical tourism competes with the local medical center for patients and their insurance dollars in a significant way. He examines the possibility that U.S. insurance plans soon may offer to pay for what is currently a cash only business and that the economic impact to the local medical center could be significant or even devastating.

Frontiers of Health Services Management [Selected Articles] 24 (2), Winter 2007.

In "Managing Healthcare Services in the Global Marketplace” (pp. 3-18), Bruce J. Fried and Dean M. Harris consider legal, ethical, and financial implications of the international workforce. In "Globalization of Health Care" (pp. 19-30), Lynn Schroth and Ruthy Khawahja point out that the transfer of comprehensive management expertise and intellectual property from U.S. medical centers to international sites is driving the success of collaboration between U.S. and foreign health care centers. In "Is Medical Tourism the Answer?" (pp. 35-40), Darrell E. Douglas comments on the appeal to American business of medical tourism as an option to provide cost effective and high quality health care for employees. Finally, in "Going Global: Delivering Health Care Services in a 'Flat' World" (pp. 41-43), Walter W. Wieners states that the model for outsourcing trends in the technology sector is emerging as the model shaping the health care delivery system, world wide.

Horowitz, Michael D., and Rosensweig, Jeffrey A. Medical Tourism- Health Care in the Global Economy. The Physician Executive: 24-30, November-December 2007. Horowitz and Rosensweig emphasize that medical tourism is market driven. It is the absence of financial resources-either insurance benefits or outright cash - that is the primary reason patients seek care in 
developing nations. Cosmetic surgery, dental reconstruction, gender reassignment operations, or fertility treatments that are not covered by insurance; procedures not available in their own countries; and the protection of privacy are medical needs being met through medical tourism. When a waiting list for a particular procedure is too long, the patient might jump the queue by paying for the procedure abroad, but then the follow-up care falls to the primary care physician when the patient returns home. The equities of this have not been resolved, either regarding the obligations of the primary care physician or others waiting patiently in the queue. The authors include data on the reasons given by patients to seek care in the developing world.

Lee, Christine. Just What the Doctor Ordered: Easy Travel to Emerging Economies with Cheaper Medical Costs Turns Medical Tourism into Big Business. Monash Business Review 3 (3): 10-13, November 2007.

Lee surveys the economic bonanza of medical tourism available to developing countries. The traveling patient benefits from the relative low cost and high quality of the medical care received. The author emphasizes the need for regulation and monitoring of the industry, including certification of staff.

Milstein, Arnold, and Smith, Mark. America's New Refugees - Seeking Affordable Surgery Offshore. New England Journal of Medicine 355 (16): 1637-40, 19 October 2006.

The referenced refugees are American patients paying the full cost of care in India or Thailand when the care available to them in the United States would bankrupt them. Based on testimony at Senate hearings, the authors describe the case of Howard Staab, self-employed and without health insurance, who needed heart surgery and elected to have it in New Delhi for a total cost of $\$ 6,700$ instead of the $\$ 200,000$ - with a 50 percent deposit due before surgery - that he faced in North Carolina. The authors analyze this example in terms of the financial burden on the patient, the quality of care and accreditation of hospitals and physicians abroad, the globalization and commodification of health care as an element of global commerce, and the impact on the care available to the local patients in the emerging economy. The authors deplore this "solution" for obtaining affordable care and see it as a symptom of the crumbling health care systems's financial framework in America.

Ramirez de Arellano, Annette B. Patients Without Borders: the Emergence of Medical Tourism. International Journal of Health Services 37 (1): 193-98, 2007.

Focusing on India and Thailand, the author draws attention to the growing phenomenon of medical tourism as patients from developed nations travel to those with emerging economies to obtain high quality health care at reduced cost. The added benefit of a luxurious vacation and recuperation in an exotic locale are also part of the appeal. By focusing national resources on care for foreigners, the host country risks denying its own citizens equitable access to care, promoting a twotiered health system defined by the economic means of the patients. Far from an innocuous outsourcing of care, the author argues that medical tourism impacts the global distribution of health care in a negative way for the local citizens. This essay points out that Bumrungrad Hospital in Bangkok is the first hospital in Asia to receive JCAHO [Joint Commission on Accreditation of Healthcare Organizations] accreditation.

Terry, Nicolas P. Symposium: The Politics of Health Law: Under-Regulated Health Care Phenomena in a Flat World: Medical Tourism and Outsourcing. Western New England Law Review 29 (2): 421-72, 2007.

Professor Terry begins with a brief survey of 
medical tourism and outsourcing, which is medical care that has been performed in part outside the U.S., a fact that may or may not be known by the patient. He believes both medical tourism and outsourcing will expand in the future, yet remain essentially unregulated globally despite concerns over health quality and data protection.

United States Senate. Special Committee on Aging. The Globalization of Health Care: Can Medical Tourism Reduce Health Care Costs? Hearing held 27 June 2006, United States Senate, Special Committee on Aging. Committee on Aging Print: 109-26.

The testimony highlights the situation for small businesses and the self-employed who must access medically necessary health care at a cost that does not lead to impoverishment and bankruptcy. Both the individual seeking care and the company benefits officer testified that the only solution they found was to seek care in India.

\section{LEGAL AND PUBLIC POLICY ISSUES}

American Medical Association. Organized Medical Staff Section (OMSS ). Medical Travel Outside the U.S. Report B, 2007. 20 p. This response by the medical establishment to the growing phenomenon of medical tourism gathers the data about who is going where for what and who is paying. Focusing on the long-term impact on medical practice in the United States, the authors discuss the reasons why Americans are going overseas, provide an overview of the medical tourism industry, and discuss the role of insurance companies in paying for these services. The report further discusses the "global convergence of medicine" - particularly in the realm of oversight, accreditation, provision for follow-up care, and legal recourse in the international arena-and makes policy recommendations, including suggestions for the AMA to provide legislative language to be enacted on the state level requiring that patients understand the risks involved in seeking care abroad.

Brady, Christopher J. Offshore Gambling: Medical Outsourcing Versus ERISA's Fiduciary Duty Requirement. Washington and Lee Law Review 64 (3): 1073-114, Summer 2007.

Brady decides that if U.S. private insurance companies and health maintenance organizations were to offer medical outsourcing, they would be in violation of the Employee Retirement Income Security Act (ERISA) of 1974. Medical outsourcing has its roots in medical tourism. Both focus on low cost surgery outside the patient's country of residence. Medical tourism describes cosmetic procedures, whereas medical outsourcing means noncosmetic procedures, ranging from relatively simple joint implants to more complicated heart bypasses and spinal surgery. "An administrator/HMO violates his duty to act 'solely in the interest' of the plan participant when he forces a participant to choose between financial windfall for both the participant and the plan, and regulated versus unregulated medical procedure."

Derckx, Veelke. Expulsion of Illegal Residents (Aliens) with Medical Problems and Article 3 of the European Convention on Human Rights (Editorial). European Journal of Health Law 13: 313-19, 2006.

The European Court of Human Rights has expanded the interpretation of Article 3 of the European Convention on Human Rights to include physical and mental health in addition to torture or inhuman or degrading treatment or punishment in cases of deportment of illegal aliens in the EU. The Court considers three elements: (1) the person's state of health; (2) the care facilities and any predictable lack of 
facilities in the home country; and (3) moral or social support in the receiving country. Derckx argues that the Court's interpretation of these three elements of "compelling humanitarian considerations" is applied at such a high threshold that human dignity is at risk. He believes that the "[i]nhuman treatment of sick persons - whether legal or illegal residents - runs counter to human dignity."

Herrick, Devon M. Medical Tourism: Global Competition in Health Care. National Center for Policy Analysis [NCPA] Report No. 304 2007 November. [Online]. Available at http://www.ncpa.org/pub/st/st304, accessed 12 April 2008.

In this policy analysis, the author presents a summary of the current trends and includes analysis of costs and the economic threshold at which patients are willing to travel for health care. The report includes the derisive view of physicians characterizing medical tourism as an unhealthy spectre of the future of health care and the economic collusion of luxury hotels and spas with international medical centers to offer concierge services for patients, supported by travel agencies throughout the trip. The author reports on the competition between emerging economic countries for the medical tourism dollar, as India offers a new visa, the medical visa, which allows longer length stays for recovery. Herrick addresses the globalization and commodification of worldwide, health care, the redirection of economic resources to support the foreign care industry, and the effect on local care as the less well-off have reduced access and longer waits for care.

Howze, Kerrie S. Note: Medical Tourism: Symptom or Cure? Georgia Law Review 41 (3): 1013-51, Spring 2007.

In her note, Howze defines a medical tourist as a consumer of medical services who travels to a foreign country because of the significantly lower cost of medical services there. In the past, patients traveled abroad for care because of a lack of access to services that were unavailable or unapproved or illegal or otherwise restricted in their home countries. She examines liability issues involving medical negligence before she concludes that medical tourism should not become a regular feature of the present U.S. health care system. She points out that because of the uniqueness of the situation where a patient in the U.S. goes to India, for example, for a specific procedure, courts may decide to follow the rule in a minority of American jurisdictions, namely New York and Hawaii, that imposes a duty of informed consent on the referring physician, not on the treating one.

Klaus, Michael. Outsourcing Vital Operations: What If U.S. Health Care Costs Drive Patients Overseas for Surgery? Quinnipiac Health Law Journal 9: 219, 235-37, 2006.

In his student note, Klaus looks at the reasons for medical tourism in Asia, specifically Thailand and India, and considers the implications of this trend for patients, insurance companies, and U.S. health care. He notes that the disparity in costs for surgery between Asia and the U.S. results from the costs of labor and medical malpractice and from the inefficiencies in processing patients. He thinks that the U.S. system of compensation for medical errors is "overly paternalistic" because no patient can opt out of paying the higher American insurance premiums by signing a waiver of the right to sue, which is the Asian practice. Thus in Asia the victims of medical errors themselves bear the costs of mistakes, a practice that lacks the social justice underpinning of the U.S. system.

Mirrer-Singer, Philip. Note: Medical Malpractice Overseas: The Legal Uncertainty Surrounding Medical Tourism. Law and Contemporary Problems 70 (2): 211-32, Spring 2007. Mirrer-Singer's article is a further 
development of the special issue "Who Pays? Who Benefits? Distributional Issues in Health Care," Law and Contemporary Problems 69 (4), Autumn 2006. MirrerSinger explains the problems with litigation and liability involving foreign defendants and concludes that legislation is needed for regulation. "The level of paternalism reflected in medical-tourism regulations should parallel the transparency of the industry. As more information about medical-tourism becomes available, there will be less need to protect medical tourists." He bases his conclusion on the fact that "information on the quality of the foreign providers [of medical services] is sparse."

Morgan, Derek. Medical Tourism: Ethical Baggage and Legal Currencies. Paper given at the British Medical Association Conference, "Medical Ethics Tomorrow," 3 December 2003. Available at http://www.bma.org.uk/ ap.nsf/Content/MedicalEthicsTomorrowConf Papers/\$file/MedTourism.pdf, accessed 14 May 2008.

Professor Morgan from Cardiff Law School describes medical tourism as two migratory types, inward and outward. He feels that allocative justice has dominated over distributive justice, or, in other words, the focus has been on what should be protected, not who should benefit from the protection. $\mathrm{He}$ calls for a "rethinking of equity in health" because of the legal recognition of medical treatments as economic services within the European Union. Two questions he cannot address at this time are: first, the obligations owed to others due to the nature of the U.K. health care delivery system, and second, the extent to which foreigners can be condemned for seeking U.K. medical services and to which U.K. citizens can be condoned for seeking medical treatment abroad.

Pennings, Guido. Ethics Without Boundaries: Medical Tourism. In Principles of Health
Care Ethics, 2d., ed. Richard E. Ashcroft, Angus Dawson, Heather Draper, and John McMillan, pp. 505-10. Chichester, West Sussex, UK; Hoboken, NJ: John Wiley \& Sons, 2007.

Pennings's entry offers an overview of the current state of the industry. He discusses conditions for acceptable cross-border health care, risks and benefits of medical tourism, how to prevent the existing system from deteriorating, benchmarks of fairness, reproductive tourism, and law evasion. He concludes that government regulation and oversight are the only brakes to be applied to this global economic engine.

\section{APPLIED AREAS: ASSISTED REPRODUCTION AND ORGAN TRANSPLANTATION}

Jones, C. A., and Keith, L. G. Medical Tourism and Reproductive Outsourcing: the Dawning of a New Paradigm for Health Care. International Journal of Fertility and Women's Medicine 51 (6): 251-55, November-December 2006.

This review article focuses on reproductive technologies available through medical tourism, drawing distinctions between obligatory and elective procedures. The authors state that "a number of factors may challenge the limits of ethics, policy and legality in this most important trend in modern medicine."

Morris, Elizabeth Ferrari. Reproductive Tourism and the Role of the European Union. Chicago Journal of International Law 8 (2): 701-13, Winter 2008.

In her student note, Morris concludes that reproductive tourism will continue within the European Union (EU) countries because there are different national regulatory schemes for assisted reproduction. She classifies those schemes by how they are designed: (1) the most liberal countries opt for nondecision (due to severely fragmented ethical viewpoints); (2) moderate countries 
with similar moral ideas depend on experts to determine the dominant medical beliefs at the time; (3) countries where there is agreement on restrictive regulation by the legislature support mobilization and consultation; and (4) countries where a shared belief about state responsibility usually support a more restrictive policy. According to Morris, the Directive 2004/23/EC on Tissues and Cells passed by the EU in 2004 reflects the EU's inclination toward regulation based in science without considering either bioethics or public discourse; she thus concludes it is inherently a weak regulation. The Directive can be read online at http://eur_lex.europa.eu/ smartapi/cgi/sga_doc?smartapi!celexapi! prod!CELEXnumdoc\&lg=en\&numdoc $=$ 32004 L0023\&model $=$ guichett , accessed 14 May 2008.

Mulay, Shree, and Gibson, Emily. Marketing of Assisted Human Reproduction and the Indian State. Development 49 (4): 84-93, December 2006.

The authors focus on the factors responsible for the phenomenal growth in the industry related to assisted human reproduction in India. They note the negative impact this industry has had on public health in India, the weak attempts at regulation, and the implications for reproductive rights and women's health.

Pennings, Guido. Legal Harmonization and Reproductive Tourism in Europe. Human Reproduction 19 (12): 2689-94, December 2004

Pennings asserts that ignoring pluralism within the states of the European Community leads to reproductive tourism. He argues against European legislation and harmonization because he believes that private ethical matters belong to the national legislative bodies. Pennings reasons that reproductive tourism reduces moral conflict and allows for the moral autonomy of individuals.
Scheper-Hughes, Nancy. The Ends of the Body: Commodity Fetishism and the Global Traffic in Organs. SAIS Review 22 (1): 61-80, Winter- Spring 2002.

The founder and director of "Organ Watch," Scheper-Hughes deplores the international trade of organs and works to make it more transparent. In this discussion, she argues that "the problem with markets is that they reduce everything-including human beings, their labor, and their reproductive capacity - to the status of commodities" and then focuses on the haves and the have nots, desperate to sell in the poor economies and desperate to live in the rich ones. This classic tension - between the kidney donors and providers, kidney sellers and brokers, and those needing kidneys with the means to buy them - underlies for the rise of medical tourism. She suggests that the classic bioethical rationale supports the notion that one has a "right" to a kidney and therefore should be free to sell or buy the commodity and argues that this is a gross injustice in economic and human terms.

Storrow, Richard F. Family Tales; the Handmaid's Tale of Fertility Tourism: Passports and Third Parties in the Religious Regulation of Assisted Conception. Texas Wesleyan Law Review 12 (1): 189-211, Fall 2005.

Storrow, a law professor at Penn State, analyzes fertility tourism in light of (1) Margaret Atwood's dystopia novel about surrogacy and (2) a three-volume ethnography of infertility and assisted reproduction in Egypt by University of Michigan anthropologist Marcia Inhorn. He describes two types of fertility tourism: One involves the infertile traveling abroad for fertility treatment, and the other involves infertile patients importing third parties for fertility treatment. Implicit in Storrow's analysis is the notion that going outside the male-female couple is like crossing a national border. 
Shimazono, Yosuke. The State of the International Organ Trade: a Provisional Picture Based on Integration of Available Information. Bulletin of the World Health Organization 85 (12): 955-62, December 2007.

In this review article, Shimazono synthesizes available data on the international trade in organs, drawing on information about the context and forms of the organ trade, the major organ-exporting and organ-importing countries; and the outcomes and consequences of commercial organ transplants. In pulling together the big picture of the organ trade, the author profiles the patients seeking transplanted organs, the countries involved in exporting, and those importing organs, and the consequences for local health as resources are drained away to support the foreign markets.

This publication was produced by staff members of the National Reference Center for Bioethics Literature (Harriet H. Gray, M.T.S., M.S.L.S. and Susan Cartier Poland, J.D.), Kennedy Institute of Ethics, Georgetown University.

Produced at the National Reference Center for Bioethics Literature, Kennedy Institute of Ethics, Georgetown University, Box 571212, Washington, DC 20057-1212. The Center operates on a contract with the National Library of Medicine, National Institutes of Health. Additional support is provided by the National Center for Human Genome Research, National Institutes of Health, and by other public and private sources.

(C) 2008 by the National Reference Center for Bioethics Literature. 